\title{
In situ measurements of speciated atmospheric mercury and the identification of source regions in the Mexico City Metropolitan Area
}

\author{
A. P. Rutter ${ }^{1}$, D. C. Snyder ${ }^{1}$, E. A. Stone ${ }^{1}$, J. J. Schauer ${ }^{1,2}$, R. Gonzalez-Abraham ${ }^{3}$, L. T. Molina ${ }^{3,4}$, C. Márquez ${ }^{5}$, \\ B. Cárdenas ${ }^{5}$, and B. de Foy ${ }^{3,6}$ \\ ${ }^{1}$ Environmental Chemistry and Technology Program, Univ. of Wisconsin, 660 N. Park Street, Madison, WI 53706, USA \\ ${ }^{2}$ Wisconsin State Laboratory of Hygiene, Univ. of Wisconsin, 2601 Agriculture Drive, Madison, WI 53718, USA \\ ${ }^{3}$ Molina Center for Energy and the Environment 2, 3262 Holiday Ct. Suite 201, La Jolla, CA 92037, USA \\ ${ }^{4}$ Massachusetts Institute of Technology, Cambridge, MA 02319, USA \\ ${ }^{5}$ Centro Nacional de Investigación y Capacitación Ambiental CENICA, Instituto Nacional de Ecología-SEMARNAT., \\ Periférico 5000, Mexico City, 04530, Mexico \\ ${ }^{6}$ Department of Earth and Atmospheric Sciences, Saint Louis University, 3642 Lindell Blvd., St. Louis, MO 63108, USA
}

Received: 16 May 2008 - Published in Atmos. Chem. Phys. Discuss.: 10 July 2008

Revised: 2 October 2008 - Accepted: 29 October 2008 - Published: 13 January 2009

\begin{abstract}
In order to expand the currently limited understanding of atmospheric mercury source-receptor relationships in the Mexico City Metropolitan Area, real time measurements of atmospheric mercury were made at a downtown urban site, and a rural site on the outskirts of Mexico City, during March 2006.

Numerous short-lived increases in particulate mercury $(\mathrm{PHg})$ and reactive gaseous mercury $(\mathrm{RGM})$ concentrations were observed at the urban site during the 17 day study, and less frequent increases in gaseous elemental mercury (GEM) concentrations were measured at both the urban and rural sites. The episodic increases observed were attributed to plume impacts from industrial point source emissions in and around Mexico City. Average concentrations and standard deviations measured during the study were as follows: i) urban site; $\mathrm{PHg}=187 \pm 300 \mathrm{pg} \mathrm{m}^{-3}$, $\mathrm{RGM}=62 \pm 64 \mathrm{pg} \mathrm{m}^{-3}, \mathrm{GEM}=7.2 \pm 4.8 \mathrm{ng} \mathrm{m}^{-3}$, and; ii) rural site; GEM=5.0 $\pm 2.8 \mathrm{ng} \mathrm{m}^{-3}$.
\end{abstract}

Several source regions of atmospheric mercury to the urban and rural sites were determined using Concentration Field Analysis, in which atmospheric mercury measurements were combined with back trajectory data to determine

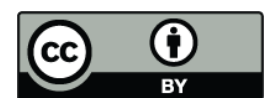

Correspondence to: J. J. Schauer (jjschauer@wisc.edu) source regions. Only some source regions correlated to mercury emission sources listed in the Federal Pollutant Release and Transfer Register, leaving the rest unaccounted for. Contributions of anthropogenic mercury point sources in and around Mexico City to concentration averages measured at the urban site during the study were estimated to be: $93 \pm 3 \%$ of reactive mercury (PHg and RGM), and; $81 \pm 0.4 \%$ of GEM. Point source contributions to GEM measured at the rural site were $72 \pm 1 \%$. GEM and reactive mercury $(\mathrm{PHg}+\mathrm{RGM})$ were not found to correlate with biomass burning at either of the measurement sites.

\section{Introduction}

Source-receptor relationships for atmospheric mercury must be accurately characterized if emission regulations intended to mitigate adverse effects on human health and protect ecosystems are to be successful. Published studies of atmospheric mercury source-receptor relationships in urban areas have revealed that point source emissions can substantially impact atmospheric concentrations of particulate mercury $(\mathrm{PHg})$, reactive gaseous mercury (RGM), and gaseous elemental mercury (GEM) (Lynam and Keeler, 2005, 2006; Poissant et al., 2005; Rutter et al., 2008; Yatavelli et al., 2006). Large urban areas typically have higher atmospheric

Published by Copernicus Publications on behalf of the European Geosciences Union. 
mercury levels than less urbanized regions due to high densities of energy production, industrial activities, and refuse incineration (Gabriel et al., 2005; Lynam and Keeler, 2005). The Mexico City Metropolitan Area (MCMA) is the second largest urban center in the world, has a high concentration of heavy industry, and is located in a basin at high altitude surrounded by mountains on three sides, which include a volcano, a likely emission source of natural mercury (Bagnato et al., 2007). Weak synoptic forcing leads to weak winds and poor mixing at night that result in poor air quality (Chow et al., 2002; Molina and Molina, 2002). Given the poor air quality, concentration of industry, and the presence of a volcano in the basin, Mexico City atmospheric mercury concentrations are likely to be substantially increased over rural background concentrations. In addition, biomass burning around the MCMA is common during the dry months of January through June and several fires and hotspots were active during the MILAGRO (Megacities Initiative: Local and Global Research Observations) sampling campaign (Yokelson et al., 2007), contributing substantially to the organic portion of atmospheric particles (Moffet et al., 2007; Stone et al., 2007). Previous publications have shown that wildfires can re-emit previously deposited atmospheric mercury (Biswas et al., 2007; Cinnirella and Pirrone, 2006; Ebinghaus et al., 2007; Friedli et al., 2003; Friedli et al., 2004; Hall et al., 2006; Obrist et al., 2008; Weiss-Penzias et al., 2007), however it is not known how much biomass burning around the MCMA affects atmospheric mercury concentrations.

At the time of writing, valuable but limited speciated measurements of atmospheric mercury in the MCMA had been published (de la Rosa et al., 2004; Querol et al., 2008), leaving incomplete the understanding of atmospheric mercury source-receptor relationships. The speciation of atmospheric mercury emissions greatly affects the distance over which a point source can impact a receptor, and therefore is central to transport and fate of atmospheric mercury. Reactive mercury (RM; defined operationally as the sum of PHg and RGM) is typically considered to be predominantly oxidized mercury compounds which are semi-volatile and water soluble (Lin and Pehkonen, 1999; Schroeder and Munthe, 1998) meaning that source emissions will impact local ecosystems through wet and dry deposition (Lin and Pehkonen, 1999; Schroeder and Munthe, 1998; Seigneur et al., 2003) Previous atmospheric modeling work has assumed that gaseous elemental mercury (GEM) partitioned to elemental carbon (EC) in urban atmospheric aerosol, thereby contributing to PHg. To our knowledge the adsorption of GEM to atmospheric EC has not been demonstrated as a significant source of PHg. Likewise, several previous publications have provided several examples where large episodic GEM increases in industrial exhaust plumes were not corroborated with concomitant increases in $\mathrm{PHg}$, indicating that GEM partitioning to atmospheric aerosol is unlikely to be an important process (Gabriel et al., 2005; Hall et al., 2006; Manolopoulos et al., 2007; Manolopoulos, 2006; Rutter et al., 2008; Yatavelli et al., 2006). Once in anoxic aquatic environments it can be converted to the neurotoxin methylmercury and bioaccumulate in the food chain (Clarkson, 1993; Jensen and Jernelov, 1969; Kainz et al., 2006; Schroeder and Munthe, 1998; Wiener et al., 2006; Wood, 1968). GEM on the other hand is volatile and oxidizes slowly allowing it to become a hemispherically well dispersed precursor for reactive mercury formation (Lin and Pehkonen, 1999; Schroeder and Munthe, 1998; Seigneur et al., 2004).

The aim of this study was to gain an initial understanding of the source-receptor relationships of atmospheric mercury in the MCMA to inform air quality management strategies, and the development of future emissions regulations. Measurements of RGM, PHg and GEM were made over 17 days using a real time ambient mercury analyzer located at a measurement site in the center of Mexico City (urban site). Real time measurements of GEM were made with a separate instrument at a site on the outskirts of the MCMA (rural site). Time series data, pollution roses, Concentration Field Analysis, and colocated measurements of the biomass burning marker levoglucosan (Fraser and Lakshmanan, 2000; Simoneit et al., 1999; Simoneit and Elias, 2001), were used to determine the characteristics and locations of RGM, PHg and GEM emission sources that impacted the urban site and the rural site.

\section{Experimental methods}

\subsection{Measurement site descriptions}

The measurements presented in this study were performed during the Megacities Initiative: Local and Global Research Observations (MILAGRO) field study between the dates of 9-25 March 2006. The sample collection and analysis equipment was located at an urban site in Mexico City center at the Instituto Mexicano de Petróleo, (designated "T0"; Lat. $19^{\circ} 29^{\prime} 21.4^{\prime \prime} \mathrm{N}$, Lon. $-99^{\circ} 08^{\prime} 51.8^{\prime \prime} \mathrm{W}$ ), and a rural site on the outskirts of the Mexico City at the Tecámac Technological University (designated "T1"; Lat. 19.70 ${ }^{\circ}$, Lon. $-98.98^{\circ}$ ) $35 \mathrm{~km}$ from the urban site. At the urban site the equipment was placed on top of a two-storey building (\#20) in the center of the premises. At the rural site filter samplers were located on an area of open ground on the northwest side of the university campus, $50 \mathrm{~m}$ away from the nearest structure. The real time mercury monitor was located inside of a semi-rigid tractor trailer, and sampled ambient air through a Teflon inlet tube suspended above the trailer roof.

Several point sources of atmospheric mercury were identified by the 2004 Pollutant Release and Transfer Register (PRTR; known as the Registro de Emisiones y Transferencia de Contaminantes in Mexico; SEMARNAT, 2006), which are listed in Table 1. It should be noted that the PRTR only includes industry that is under Federal jurisdiction, omitting industry controlled by States and Municipalities. The 2004 
Table 1. Mercury point source locations, industrial process at the facility under Federal jurisdiction leading to the emissions, and kilograms of total mercury (i.e. GEM and/or RM) emitted during 2004. Facility and emission data were collected from the Pollutant Release and Transfer Register (SEMARNAT, 2006).

\begin{tabular}{|c|c|c|c|c|c|}
\hline $\begin{array}{c}\text { ID \# } \\
\text { in Fig. } 3\end{array}$ & $\begin{array}{c}\text { Location } \\
\text { (City, State) }\end{array}$ & Lat. N, Long. W & $\begin{array}{c}\text { UTM x, } \\
\text { UTM y (km) }\end{array}$ & Process & $\begin{array}{l}2004 \text { Emissions } \\
(\mathrm{kg})\end{array}$ \\
\hline 1 & Huichapan, Hidalgo & $20^{\circ} 23^{\prime} 7^{\prime \prime}, 99^{\circ} 41^{\prime} 4^{\prime \prime}$ & $428.6,2255.4$ & Cement Production & 26 \\
\hline 2 & Tula de Allende, Hidalgo & $19^{\circ} 57^{\prime} 24^{\prime \prime}, 99^{\circ} 22^{\prime} 15^{\prime \prime}$ & $461.9,2206.8$ & Cement Production & 142 \\
\hline 3 & Tula de Allende, Hidalgo & $20^{\circ} 1^{\prime} 0^{\prime \prime}, 99^{\circ} 15^{\prime} 0^{\prime \prime}$ & $472.5,2216.6$ & Petroleum Refining & 12 \\
\hline 4 & Atotonilco de Tula, Hidalgo & $20^{\circ} 21^{\prime} 43^{\prime \prime}, 99^{\circ} 12^{\prime} 28^{\prime \prime}$ & $477.8,2210.2$ & Cement Production & 1 \\
\hline 5 & Ecatepec de Morelos, Mexico & $19^{\circ} 28^{\prime} 0^{\prime \prime}, 99^{\circ} 14^{\prime} 0^{\prime \prime}$ & $475.6,2152.4$ & Paper and Cardboard Production & 2 \\
\hline 6 & Ecatepec de Morelos, Mexico & $19^{\circ} 32^{\prime} 28^{\prime \prime}, 99^{\circ} 15^{\prime} 0^{\prime \prime}$ & $505.5,2160.7$ & Chemical Production & 1 \\
\hline 7 & Cuautinchan, Puebla & $19^{\circ} 5^{\prime} 23^{\prime \prime}, 97^{\circ} 57^{\prime} 52^{\prime \prime}$ & $609.5,2097.5$ & Cement Production & 33 \\
\hline 8 & Toluca, Mexico & $19^{\circ} 17^{\prime} 13^{\prime \prime}, 99^{\circ} 35^{\prime} 66^{\prime \prime}$ & $460.2,2132.7$ & Beer Production & 1 \\
\hline
\end{tabular}

Emissions Inventory for the MCMA (CAM, 2006) revealed that industrial facilities were located throughout the MCMA, and that particularly dense clusters of facilities were located close to the urban site: 1) over a $10 \mathrm{~km}^{2}$ area to the west; 2 ) $10 \mathrm{~km}$ to the east, and; 3) $15 \mathrm{~km}$ to the south. The rural site was located in an agricultural region, where there was much less heavy industry than surrounded the urban site. To the south of the campus there were residential areas with associated vehicle traffic, and uncontrolled refuse incineration.

\subsection{Real time ambient mercury measurements}

Real time semi-continuous measurements of GEM, PHg, and RGM were made using the Tekran Ambient Mercury Analyzer at the urban site "T0". The Tekran AMA consisted of a potassium chloride ( $\mathrm{KCl})$ coated denuder (Tekran 1130) to collect RGM (Landis et al., 2002a), and a particle filter (Tekran 1135) directly after to collect PHg (Lu et al., 1998; Lynam and Keeler, 2002), followed by a cold vapor atomic fluorescence spectrometer (CVAFS; Tekran 2537A) to measure GEM, which used gold amalgamation to preconcentrate the sample (Fitzgerald and Gill, 1979). The RGM and PHg modules were heated to $50^{\circ} \mathrm{C}$ and mounted on a mast that elevated the inlet of the Tekran $1.5 \mathrm{~m}$ above the nearest surface. The aerosol was drawn into the Tekran AMA at 10 liters per minute through an elutriator containing an inertial impactor that removed particles larger than $2.5 \mu \mathrm{m}$ in diameter. Collection of RGM and PHg was conducted for one hour, during which time measurements of GEM were made every 5 min. At the end of the sample collection period the RGM was recovered from the $\mathrm{KCl}$ denuder by heating to $500^{\circ} \mathrm{C}$ thereby thermally reducing the RGM to GEM. Downstream of the denuder a quartz chip pyrolyzer was heated to $900^{\circ} \mathrm{C}$ to ensure the complete conversion of any unreduced RGM compounds that were evolved during the heating of the denuder. The GEM evolved from the denuder was then purified using soda lime and quantified using the CVAFS. The particulate mercury was recovered from the particle filter by heating it to $850^{\circ} \mathrm{C}$. The gaseous products released during the thermal desorption were pyrolyzed at $850^{\circ} \mathrm{C}$, and the evolved GEM was quantified. Previous studies have indicated that a negative artifact in $\mathrm{PHg}$ measurements may have occurred in measurement studies at ambient temperatures below $30^{\circ} \mathrm{C}$ (Rutter et al., 2007; Rutter and Schauer, 2007a). The root cause of the artifact was not determined by these studies, and it is still unknown whether this phenomenon is applicable to all sampling locations, or just a select few. Furthermore, insufficient supporting data were available at the urban site to permit an accurate correction should the artifact have occurred during this study. Therefore, no attempts to adjust the $\mathrm{PHg}$ measurements collected during this study were made, although the reader should be aware that the PHg concentrations reported here could be systematically low, especially during the cooler nighttime hours.

The real time GEM measurements were made at the rural site "T1" with a Tekran 2537A without either of the speciation modules attached to the inlet. Instead aerosol was passed through a particle filter and a soda lime trap. The inlet to the instrument was suspended above the roof of the semi trailer.

\subsection{Concentration field analysis}

Concentration Field Analysis was used to determine source locations of GEM, PHg and RGM, by combining time series of concentration measurements with back-trajectories that were calculated using FLEXPART and WRF meteorological simulations (Michalakes et al., 1998; NCAR, 2008; Siebert et al., 1994; Stohl et al., 2005). Every hour 100 particles were released from the urban site and were tracked backwards for $48 \mathrm{~h}$. The particle locations were stored at hourly intervals along the backward trajectories. A grid was laid over the MCMA to allow the particle location data to be converted to a "Residence Time" grid by counting the number of particles in each grid cell, in a manner analogous to a time exposure photograph. The Residence Time grids were then scaled by pollutant concentrations and summed over the entire sample 
collection period. The Concentration Field Analysis (CFA) was obtained by performing the following steps: i) the Residence Time grids scaled by concentration were summed over the sample collection period; and, ii) normalized for preferred wind transport directions by dividing by the sum of the Residence Time grids that had not been scaled by concentration. In this way, source regions associated with high concentrations of PHg, RGM and GEM were indicated with high CFA values, whereas flow regions associated with clean air were indicated with low CFA values.

\subsection{Levoglucosan collection and analyses}

The contribution of biomass burning to atmospheric particles was measured by analyzing collected particles for levoglucosan (1,6-anhydro- $\beta$-D-glucopyranose), a specific marker for biomass burning (Schauer and Cass, 2000; Simoneit et al., 1999; Stone et al., 2008). The particulate matter was collected every day and night at the urban and rural sites on precleaned quartz fiber filters in a Teflon coated medium volume sampler (URG-3000-B, URG Corp., Chapel Hill, NC) in two 12-h segments: 06:00-18:00; and 18:00-06:00. The quartz fiber filters were pre-cleaned by baking at $550^{\circ} \mathrm{C}$ for $15 \mathrm{~h}$, and stored in foil lined Petri dishes sealed with Teflon tape. Substrates were stored at $-20^{\circ} \mathrm{C}$ after collection, and shipped from Mexico City to UW-Madison at $0^{\circ} \mathrm{C}$. Segments of the filters were cut out for use in the solvent extractions, and in most extractions segments of the 12-h substrates were combined to give 24-h composited samples. The only exception was the 19 March 2006 sample collected at the urban site, for which only the 06:00 to 18:00 sample was available. The samples were analyzed for levoglucosan using the method described in previous publications (Nolte et al., 2002; Sheesley et al., 2004; Stone et al., 2008) and so will be only briefly discussed here. The filters were spiked with an internal standard of isotopically labeled levoglucosan $-{ }^{13} \mathrm{C}_{6}$ (Cambridge Isotope Laboratories, Andover, MA). The levoglucosan was extracted from the filters using a soxhlet extraction with dimethyl chloride $\left(\mathrm{CH}_{2} \mathrm{Cl}_{2}\right)$ and methanol $\left(\mathrm{CH}_{3} \mathrm{OH}\right)$ solvents (Sheesley et al., 2004). The extracts were concentrated by rotary evaporation and by passing nitrogen over the top of the extract. The aliquots were derivatized with N,O-bistrimethylsilyl)trifluoro-acetamide with $1 \%$ trimethylchlorosilane (Fluka, Buchs, Switzerland) to convert all of the hydroxyl functional groups into trimethylsilyl ethers, thereby greatly increasing the volatility of the levoglucosan. The aliquots were sealed and heated to $70^{\circ} \mathrm{C}$ for $3 \mathrm{~h}$ to complete the derivatization, after which the samples were immediately analyzed. The components of each extract were separated using a $6890 \mathrm{~N}$ Network Gas Chromatograph (GC) system and analyzed using a 5973 Mass Selective Detector (Agilent Technologies, Santa Clara, CA) (Nolte et al., 2002). The GC column was a model HP-5MS ( $30 \mathrm{~mm} \times 0.25 \mathrm{~mm} \times 0.25 \mu \mathrm{m}$; Hewlett Packard, Palo Alto, CA). The oven temperature profile started with a $10 \mathrm{~min}$ hold at $65^{\circ} \mathrm{C}$, after which the temperature was increased at $10^{\circ} \mathrm{C} / \mathrm{min}$ for $26.50 \mathrm{~min}$ until it reached $300^{\circ} \mathrm{C}$. The temperature was then held at $300^{\circ} \mathrm{C}$ for the next $23.50 \mathrm{~min}$. The limit of detection was defined as 3 times the standard deviation of the average of the blanks, which was $25 \mathrm{ng} \mathrm{m}^{-3}$. All of the samples were well above the detection limit. Uncertainties in the levoglucosan concentrations were represented by the quadrative sum of 3 times the standard deviation of the analytical blank averages, and the dominant measurement uncertainty, which was the $\pm 20 \%$ QAQC constraint for the recovery of internal standards added to the sample before extraction and derivatization. All of the samples were well above the detection limit which was quantified as twice the standard deviation of the analytical blanks.

\subsection{Meteorological data}

Wind direction and temperature measurements were made at the urban site and the rural site using Model WXT510 Vaisala Weather Transmitters (Woburn, MA). Data was collected at $1 \mathrm{~Hz}$ and reported as 2 min averages.

\section{Results and discussion}

3.1 Characterization of plume impacts at the urban and rural sites

Reactive mercury (RM; sum of $\mathrm{PHg}$ and RGM) and gaseous elemental mercury (GEM) were measured semicontinuously between 9 March 2006, 00:00 (Central Standard Time) and 25 March 2006, 12:00 at the urban site. GEM was measured at the rural site between 9 March 2006, 00:00 and 25 March 2006, 23:59. Time series plots of these measurements are presented in Fig. 1a, b, and c. The RM concentrations (a) were measured as hourly averages every other hour. The GEM concentrations at the urban site (b) were measured as 5 min averages during the hours when RM samples were being collected. GEM concentrations at the rural site (c) were measured as 5 minute averages throughout the sample collection period.

Several short-lived increases in concentration (on the time scale of a few hours or less) were seen in all of the RM and GEM time series. Particular characteristics of the time series led to the hypothesis that the episodic increases were predominantly due to encounters with plumes from point sources in the MCMA, as has been reported in other cities by previous publications (Gabriel et al., 2005; Lynam and Keeler, 2005, 2006; Poissant et al., 2005; Rutter et al., 2008; Yatavelli et al., 2006): i) the irregular frequency and highly variable maximum concentrations of the encounters; ii) the rate of concentration increase and decrease at the event boundaries; and, iii) the time of day of the episodes (especially at the urban site, which were mainly at night). The measurements of RM at the urban site revealed a large number of plume impingements on the sampling site. However, 

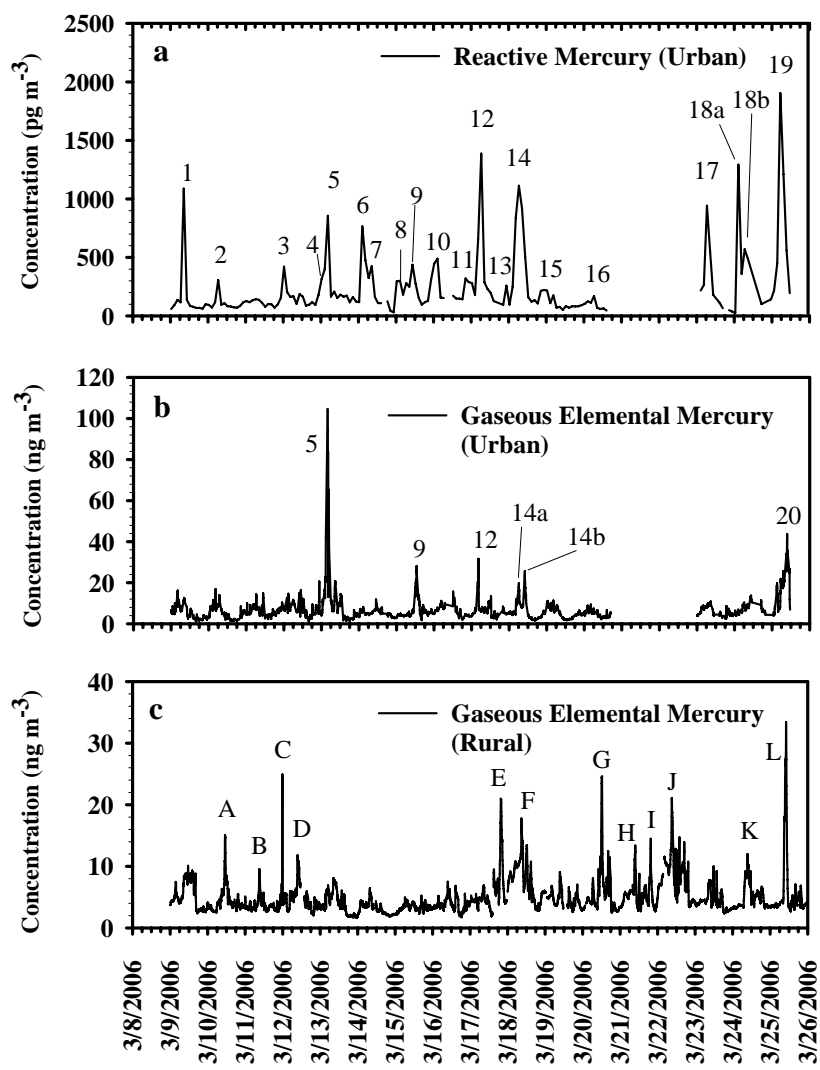

Fig. 1. Time series plots of reactive mercury at the urban site (a), gaseous elemental mercury at the urban site (b), and gaseous elemental mercury at the rural site (c). Reactive mercury measurements were one hour averages made every other hour. Gaseous elemental mercury measurements at the urban site were $5 \mathrm{~min}$ averages made during the hour periods when reactive mercury was measured. Gaseous elemental mercury measurements at the rural site were 5 min averages made throughout the sample collection period. Plumes are annotated with identification numbers (the urban site) and letters (the rural site).

only four of the $19 \mathrm{RM}$ plume events correlated with substantial GEM plume events, indicating that most of the plumes came from sources that emitted enough RM to produce large impacts on atmospheric concentrations, but that did not emit enough GEM to change concentrations significantly above the urban background. It is also possible that the speciation of emissions from some facilities may have changed with time.

It is pertinent at this point to understand how the diurnal meteorological patterns within the MCMA worked in concert with emission sources to influence the mercury concentrations measured at the urban and rural sites. A thorough review of the meteorology during the MILAGRO campaign was presented by (de Foy et al., 2008; Fast et al., 2007) who revealed that air flow to the urban and rural sites on most days could be generally divided into three periods: 1) flow from the north and west between midnight and 07:00; 2) flow

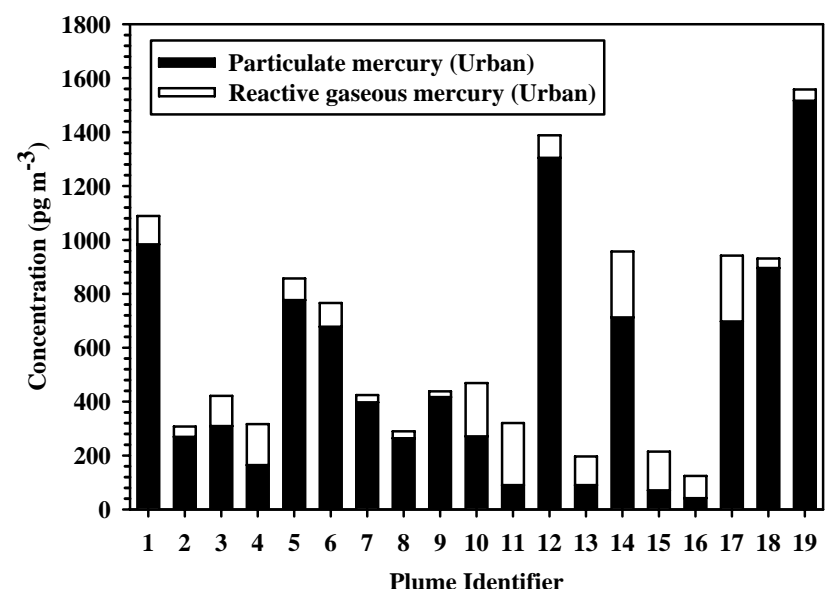

Fig. 2. Absolute concentrations of particulate mercury and reactive gaseous mercury measured at the maximum of each plume event observed at the urban site.

predominantly from the east with some air masses approaching from the north, north east, and southeast between 07:00 and early afternoon; and 3) flow from the southeast, south or north throughout the afternoon until midnight. Most of the plume incursions seen at the urban site occurred at night, consistent with transport of emissions from the industrial sources to the north and west. Exceptions to this were plumes 15 and 16 (Fig. 1) which were associated with transport from the south and southeast. The majority of plume incursions at the rural site occurred during the mid to late morning which were normally associated with changing wind patterns and were either due to transport from the industrial sources to the north or from the sources inside or to the south and south east of the MCMA.

Increases in both PHg and RGM were seen in all the RM plume events annotated in Fig. 1, and in most cases $\mathrm{PHg}$ and RGM concentration increases were concomitant (Fig. S1: http://www.atmos-chem-phys.net/9/207/2009/ acp-9-207-2009-supplement.pdf), implying that they were from the same source, or from different facilities located along the same trajectory. In a few cases PHg and RGM increases were slightly separated in time but still partially overlapped, indicating a dynamic change in speciation, or impingements from distinct sources with different speciation characteristics located on similar trajectories such that their plumes were partially superimposed. Figure 2 and Table 2 show how the ratios of PHg and RGM at the plume maxima varied according to the impact episode. In many of the plume events PHg was the dominant species, although RGM dominated in plumes 11,15 and 16. Speciation ratios of reactive mercury, provided by the 2002 USEPA National Emissions Inventory to characterize emissions from broadly defined source types (USEPA, 2002), are affected by several factors making the identification and modeling of sources using this parameter problematic: i) the contrast between ambient 
Table 2. The percentages of particulate mercury and reactive gaseous mercury at plume event maxima.

\begin{tabular}{lrrr}
\hline Plume Identifier & \% PHg & \% RGM & RM:GEM Ratio \\
\hline 1 & 90.3 & 9.7 & 0.10 \\
2 & 87.5 & 12.5 & 0.03 \\
3 & 73.5 & 26.5 & 0.06 \\
4 & 51.9 & 48.1 & 0.05 \\
5 & 90.6 & 9.4 & 0.01 \\
6 & 88.5 & 11.5 & 0.12 \\
7 & 93.6 & 6.4 & 0.08 \\
8 & 89.9 & 10.1 & 0.07 \\
9 & 95.2 & 4.8 & 0.07 \\
10 & 69.7 & 30.3 & 0.07 \\
11 & 28.2 & 71.8 & 0.07 \\
12 & 94.0 & 6.0 & 0.19 \\
13 & 78.0 & 22.0 & 0.05 \\
$14 \mathrm{a}$ & 93.9 & 6.1 & 0.08 \\
$14 \mathrm{~b}$ & 72.9 & 27.1 & 0.03 \\
15 & 47.8 & 52.2 & 0.04 \\
16 & 49.5 & 50.5 & 0.03 \\
17 & 74.0 & 26.0 & 0.11 \\
$18 \mathrm{a}$ & 96.5 & 3.5 & 0.23 \\
$18 \mathrm{~b}$ & 95.7 & 4.3 & 0.07 \\
19 & 97.9 & 2.1 & 0.13 \\
20 & 96.2 & 3.8 & 0.02 \\
\hline & & & \\
\hline
\end{tabular}

temperature (Rutter and Schauer, 2007a) and plume temperature, and the kinetics of reactive mercury repartitioning upon thermal equilibration with the atmosphere; ii) the RM compound and particle composition (Rutter and Schauer, 2007b); iii) operational conditions of the generating process, i.e. combustion conditions and fuel composition (Pavlish et al., 2003); and, iv) the possibility that different source processes might generate similar $\mathrm{PHg} / \mathrm{RGM}$ speciation ratios. As mentioned above reactive mercury is semi-volatile (Landis et al., 2002a; Lin and Pehkonen, 1999; Lynam and Keeler, 2005; Schroeder and Munthe, 1998) and ambient temperature affects the distribution of reactive mercury between the gas and particle phases (Rutter and Schauer, 2007a). Therefore, care should be exercised in comparing the distributions of PHg and RGM between plumes. Events 11, 15 and 16 were measured in the middle of the temperature range observed during the field study $\left(9-29^{\circ} \mathrm{C}\right)$ and so the predominance of RGM over PHg could either be due to the plume not yet having reached thermal equilibrium, or the other factors mentioned in ii)-iv).

\subsection{Identification of mercury source regions}

Figure 1 revealed that the urban site and the rural site were impacted by plumes from point sources in and around the Mexico City Metropolitan Area (MCMA). The objectives of this study were to identify source regions of atmospheric mercury to the urban and rural sampling sites, and to provide quantitative estimates of how atmospheric concentrations were affected by anthropogenic emission sources located in these regions. The latter objective will be pursued in the next section. The MCMA Emissions Inventory (CAM, 2006) revealed that industrial facilities were located throughout the city and surrounding region, as presented above in the site description section. The 2004 Federal Pollutant Release and Transfer Register (PRTR; SEMARNAT, 2006) reported total mercury emissions from known point sources in the MCMA, giving no speciation information (Table 1).

In order to evaluate published understanding of mercury emissions and to determine the relationship between the measurement sites and mercury point source locations in the MCMA, Concentration Field Analysis (CFA) was performed. The CFA method was evaluated using transport of carbon monoxide: the emissions sources in Mexico City have been well characterized and were correctly identified (de Foy et al., 2007; Stohl et al., 2005). Figure 3a to d present CFA results for the RM, PHg, RGM, and GEM samples collected at the urban site (T0), and Fig. 3e depicts the GEM samples collected at the rural site. Source location signatures were represented as dark areas. Light areas indicated an absence of source impacts on the measurement site, although sources may have been located in these areas that affected other regions of the MCMA. The range of shading between the light and dark areas is indicative of the contribution of each source region to the average concentrations measured during the study. It is important to recognize that the CFA results from this study provide perspective of how point sources in and around the MCMA affect atmospheric mercury concentrations at the measurement sites. However, the CFA cannot evaluate the impact of the emissions from mercury point sources that did not, or only rarely impacted the measurement sites during the 17-day study. Such point sources may have impacted atmospheric concentrations in other regions of the MCMA more or less substantially than was observed at the measurement sites used in this study. Relationships between point sources and measurement sites may also change throughout the year as seasonal variations in weather patterns occur. In order to properly assess the impacts of mercury point sources to the MCMA, a more extensive monitoring campaign and CFA will need to be conducted in which multiple monitoring sites throughout the region are established and operated for at least one calendar year. The method is much better at determining the direction of a source than its distance from the receptor site. Therefore, large sources often had a high signature for the entire trajectory between the source and the receptor site. The results of each CFA analysis were overlaid with the Federal District boundary (gray line), topography contours (solid black lines), satellite cities, and known point source locations from the PRTR (SEMARNAT, 2006) which were designated with numbers assigned in Table 2. 


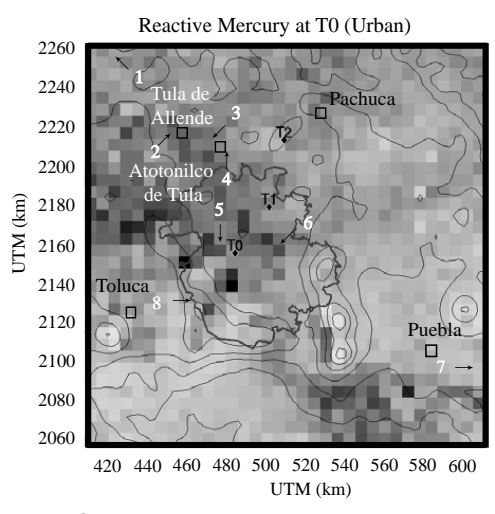

$\mathrm{a}$

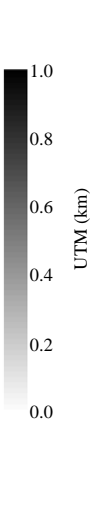

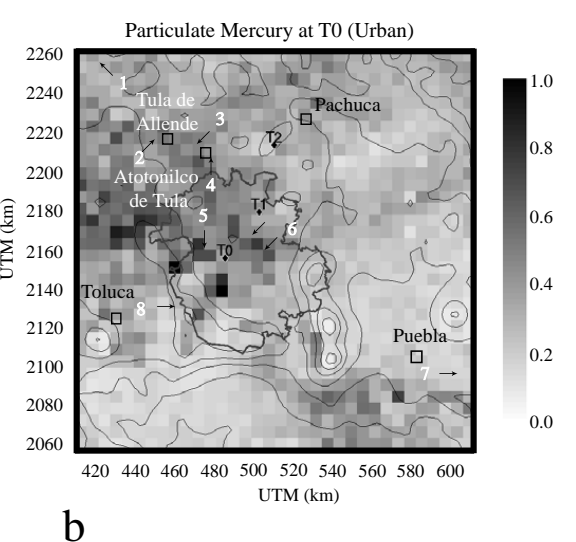

b

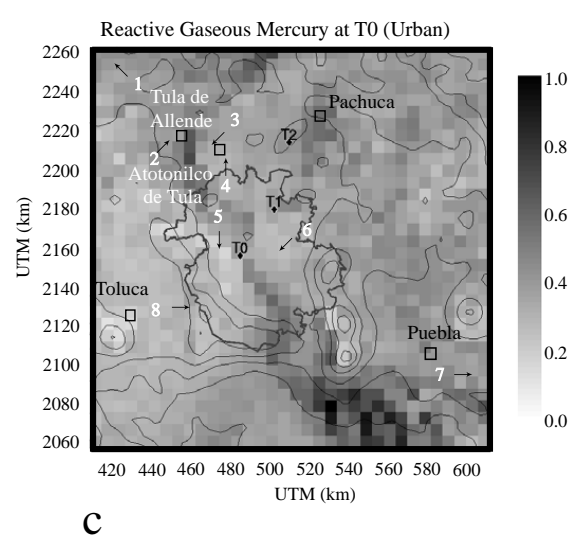

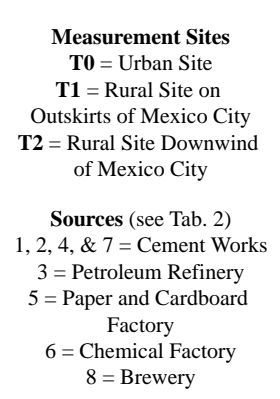

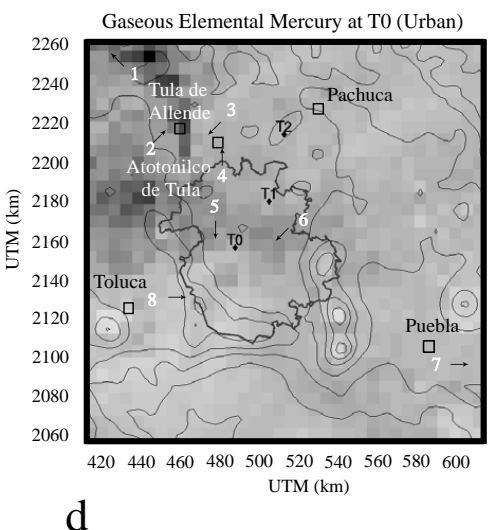

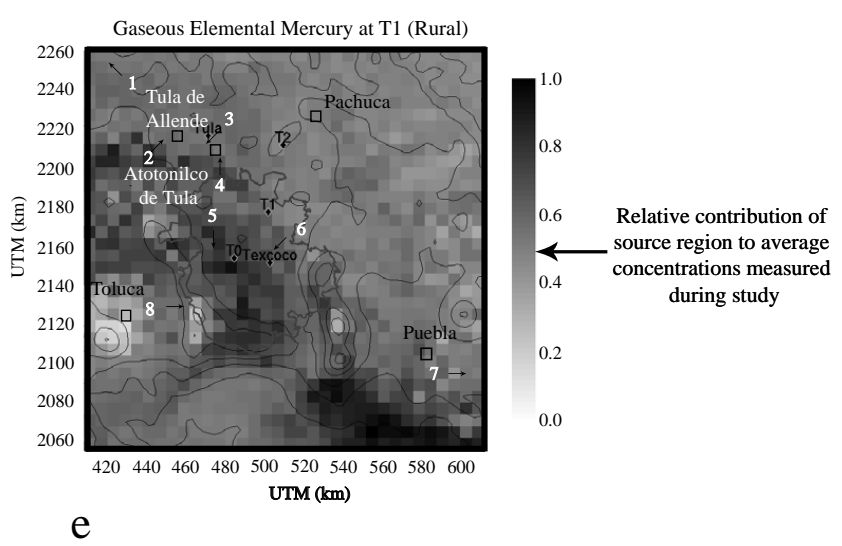

Fig. 3. Concentration Field Analysis for reactive mercury (a), particulate mercury (b), reactive gaseous mercury (c), and gaseous elemental mercury at the urban site (d), along with gaseous elemental mercury at the rural site (e). Each figure is annotated with point source locations from the 2004 Pollutant Release and Transfer Register (Table 2).

Figure 3a presents the CFA results for RM which were broken down into the PHg and RGM components in Fig. 3b and c, respectively. Collectively these figures revealed source regions in the following areas: $(\mathrm{N})$ to the north and northwest located very close to the cities of Tula de Allende, and Atotonilco de Tula, and another area to the north east close to Pachuca, and the measurement site T2 (outside of the MCMA); (E) to the east of the urban site; (SE) at various distances to the south east of the urban site; (SW) to the southwest of the urban site, and; (W) to the west (both inside and outside of the Federal District).

The signatures from Region $\mathrm{N}$ were characteristic of longer range transport from well defined sources and were likely due mostly to the cement works at Tula de Allende, Atotonilco de Tula, and Huichapan in Hidalgo State. The area to the northeast appears to also host a point source of RM in a location that was consistent with the city of Pachuca, but no such source was listed in the PRTR for this area, or for Veracruz-Llave, the next state to the northeast.
Source Region E contained source regions close to the urban site which could have been due to the chemical manufacturing at Ecatepec de Morelos, Mexico State, but were difficult to distinguish above the strong source signatures from source region $\mathrm{N}$. There appeared to be an additional source region located in the valley to the east of the Federal District which was not listed in the PRTR, but was consistent with the locations of several small towns.

Source Region SE consisted of several sub-regions. The first was a strong signature from a location consistent with the Cuautinchan cement factory located close to the city of Puebla. Although this was the only facility listed in the PRTR it is quite possible that more unregistered mercury sources around Puebla contributed to the observed source region, including those under State or Municipal jurisdiction. There were also source signatures of RM, PHg, and RGM, which were consistent with the Popocatepetl volcano, although these source regions could actually have been plumes originating from the Puebla area. More detailed source apportionment using chemical markers unique to volcanoes will need to be employed to confirm the contribution of the 
Popocatepetl to the urban site. The industrial pocket 10$15 \mathrm{~km}$ south east of the urban site reported in the MCMA Emissions Inventory (CAM, 2006) correlated with PHg and RGM source signatures in Fig. $3 b$ and c. However, this area was located underneath the trajectory of the Puebla/Volcano plume, making if difficult to assess the origin of these signatures.

Source Region SW to the southwest of the urban site was thought to be due to unregistered mercury sources in the Vallejo industrial area, and the southern region of the MCMA.

Source Region W was composed of a large area to the west of the urban site which encompassed the Vallejo industrial district, Toluca, the Toluca Industrial Park, and several small cities west of $450 \mathrm{~km} \mathrm{UTM}$ and north of $2160 \mathrm{~km} \mathrm{UTM}$. A registered paper and cardboard manufacturing business corresponded well with source signatures immediately west of the urban site, and a brewery, situated in the Toluca Industrial Park correlated reasonably well with a source located at UTM coordinates $470 \mathrm{~km}, 2130 \mathrm{~km}$. However, many other source signatures detected in Region W were not registered in the PRTR, and appeared to be located predominantly in the Vallejo industrial district, and the previously mentioned cities to the west and northwest of the MCMA.

Figure $3 \mathrm{~d}$ shows potential source regions identified by CFA for GEM plume impacts at the urban site. The Source Regions N, E, SW, and W reported for RM, PHg and RGM in Fig. 3a-c were also observed for GEM in Fig. 3d. GEM plume impacts at the urban site were dominated by emissions transported from the sources in Regions N and W. Transport of GEM from Region SE was suggested, but was not as strong as indicated by Fig. 3a-c. The source regions indicated for GEM and RM by the CFAs agreed well with each other, implying that the majority of GEM and RM source emissions occurred in the same areas, even if they did not always originate from the same facilities.

Figure $3 \mathrm{e}$ shows the CFA results for GEM measurements made at the rural site (T1). Source Region W was combined with Source Region SW because no distinction between the two regions could be made from the rural site. The data presented corroborated Source Regions N, SE, S, and W. However the source signatures to the near west and in Regions SE and SW were much stronger and more extensive, than in Fig. 3d, whilst Source Region (E) looked more widespread. Furthermore, the exact locations of the emission sources in Region $\mathrm{N}$ differed slightly between the urban and rural GEM analyses. All of the differences were probably due to two factors: i) the GEM data set at the urban site only contained measurements during every other hour, whereas at the rural site GEM measurements were made continuously; and, ii) the air masses arriving at the rural site may have been influenced by the different areas of the MCMA than those arriving at the urban site, providing a different perspective of GEM emission sources throughout the basin. Overall the GEM CFA analyses between the urban site and the rural site both qualitatively identified the same source regions of GEM throughout the MCMA, providing confidence in the analytical method.

\subsection{Directional source apportionment of mercury emis- sions to average concentrations}

A starting point of an air quality management strategy for mercury is to determine which sources are contributing the most to observed mercury concentrations and concentrate mitigation efforts on those first. This study builds on the basis provided by the PRTR for such a strategy by presenting a source apportionment of speciated mercury concentration measurements made at the urban and rural sites. The source apportionment calculations were performed using the method described in (Rutter et al., 2008) and will only be mentioned briefly here. Plume impingements from point sources were identified as increases in atmospheric concentrations above a threshold value determined to be indicative of the regional background. A review of GEM monitoring data collected throughout the western northern hemisphere (Rural values in Table 3); (Ebinghaus et al., 2002; Kim et al., 2005; Slemr et al., 2003; Swartzendruber et al., 2006; Weiss-Penzias et al., 2006) revealed that GEM concentrations averaged at about $1.5 \pm 0.2 \mathrm{ng} \mathrm{m}-3$ (1SD) when no local anthropogenic or natural sources (point or area) were influencing the air mass. This concentration therefore represents the western northern hemispheric background. When minimum hourly concentration averages measured during this study (urban GEM=2.0 $\mathrm{ng} \mathrm{m}^{-3}$; rural GEM=1.8 $\mathrm{ng} \mathrm{m}^{-3}$ ) were compared to the western northern hemisphere background, it was decided that the rural and urban sites were too frequently influenced by mercury emissions from industry or re-emitted mercury from environmental surfaces to extract reliable threshold concentrations from the data sets. Re-emitted mercury was thought to be predominantly recently deposited mercury, and therefore primarily anthropogenic in origin, rather than a historic legacy of deposition from Popocatepetl Volcano which would have been progressively buried in soil columns with the passing of time. To obtain a GEM threshold concentration that represented the regional background in Mexico, published measurements made outside of Mexico City at a rural location and pacific coastal location were used (de la Rosa et al., 2004). The GEM threshold concentration was determined to be $1.4 \pm 0.1 \mathrm{ng} \mathrm{m}^{-3}$, which was not statistically different than the western northern hemispheric background. A paucity in the published literature of rural PHg and RGM measurements made in Mexico meant that an RM threshold value had to be estimated from previous published studies performed outside of Mexico. A range of threshold values were determined for PHg and RGM using: i) the smallest concentration measured at the urban site, which corresponded to the Tekran 1130 and 1135 limit of detection of $3 \mathrm{pg} \mathrm{m}^{-3}$; and, ii) the largest average rural concentrations $\left(\mathrm{PHg}=24 \mathrm{pg} \mathrm{m}^{-3}\right.$, 
Table 3. Average particulate mercury (PHg) and reactive gaseous mercury (RGM) concentrations (including plume impacts) in rural and urban locations. Uncertainties are represented with 1 standard deviation.

\begin{tabular}{|c|c|c|c|c|c|c|c|c|}
\hline & \multirow[b]{2}{*}{ City } & \multicolumn{2}{|c|}{$\begin{array}{c}\mathrm{PHg} \\
\left(\mathrm{pg} \mathrm{m}^{-3}\right)\end{array}$} & \multicolumn{2}{|c|}{$\begin{array}{c}\text { RGM } \\
\left(\mathrm{pg} \mathrm{m}^{-3}\right)\end{array}$} & \multicolumn{2}{|c|}{$\begin{array}{c}\text { GEM } \\
\left(\mathrm{ng} \mathrm{m}^{-3}\right)\end{array}$} & \multirow[b]{2}{*}{ Reference } \\
\hline & & Avg & Std Dev & Avg & Std Dev & Avg & Std Dev & \\
\hline \multirow[t]{13}{*}{ Urban } & Mexico City, D.F. (T0) & 187 & 300 & 62 & 64 & 7.2 & 4.8 & This study \\
\hline & Milwaukee, WI & 12 & 15 & 10 & 14 & 2.5 & 1.1 & (Rutter et al., 2008) \\
\hline & East St Louis, IL & 483 & 1954 & 737 & 2862 & 4.6 & 6.0 & (Manolopoulos, 2006) \\
\hline & Tuscaloosa, AL & 16 & 20 & 14 & 20 & 4.1 & 1.3 & (Gabriel et al., 2005) \\
\hline & Detroit, MI & $18-19^{\mathrm{a}}$ & $\mathrm{n} / \mathrm{a}$ & $6-22^{a}$ & $\mathrm{n} / \mathrm{a}$ & $1.7-3.1^{\mathrm{a}}$ & $\mathrm{n} / \mathrm{a}$ & (Lynam and Keeler, 2005) \\
\hline & Chicago, IL & 70 & 67 & $\mathrm{n} / \mathrm{a}$ & $\mathrm{n} / \mathrm{a}$ & 3.6 & 2.9 & (Landis et al., 2002b) \\
\hline & Connecticut & $6-7^{b}$ & $\mathrm{n} / \mathrm{a}$ & $\mathrm{n} / \mathrm{a}$ & $\mathrm{n} / \mathrm{a}$ & $2.2-2.7^{\mathrm{b}}$ & $\mathrm{n} / \mathrm{a}$ & (Nadim et al., 2001) \\
\hline & Tokyo, Japan & 98 & 51 & $\mathrm{n} / \mathrm{a}$ & $\mathrm{n} / \mathrm{a}$ & 2.7 & 3.6 & (Sakata and Marumoto, 2002) \\
\hline & Mexico City, D.F. (CENICA) & $\mathrm{n} / \mathrm{a}$ & $\mathrm{n} / \mathrm{a}$ & $\mathrm{n} / \mathrm{a}$ & $\mathrm{n} / \mathrm{a}$ & 9.8 & 4.8 & (de la Rosa et al., 2004) \\
\hline & Toronto, Canada & $\mathrm{n} / \mathrm{a}$ & $\mathrm{n} / \mathrm{a}$ & $\mathrm{n} / \mathrm{a}$ & $\mathrm{n} / \mathrm{a}$ & 2.6 & 2.4 & (Denis et al., 2006) \\
\hline & Grenoble, France (Suburban) & $\mathrm{n} / \mathrm{a}$ & $\mathrm{n} / \mathrm{a}$ & $\mathrm{n} / \mathrm{a}$ & $\mathrm{n} / \mathrm{a}$ & 3.4 & 3.6 & (Dommergue et al., 2002) \\
\hline & Seoul, Korea & $\mathrm{n} / \mathrm{a}$ & $\mathrm{n} / \mathrm{a}$ & $\mathrm{n} / \mathrm{a}$ & $\mathrm{n} / \mathrm{a}$ & 5.1 & 2.5 & (Kim et al., 2005) \\
\hline & Beijing, China & $\mathrm{n} / \mathrm{a}$ & $\mathrm{n} / \mathrm{a}$ & $\mathrm{n} / \mathrm{a}$ & $\mathrm{n} / \mathrm{a}$ & $8.3-24.7^{\mathrm{b}}$ & $3.1-24.8^{\mathrm{b}}$ & (Liu et al., 2002) \\
\hline \multirow[t]{11}{*}{ Rural } & Mexico City, D.F. (T1) & $\mathrm{n} / \mathrm{a}$ & $\mathrm{n} / \mathrm{a}$ & $\mathrm{n} / \mathrm{a}$ & $\mathrm{n} / \mathrm{a}$ & 5.0 & 2.8 & This study \\
\hline & Huejutla, Mexico & $\mathrm{n} / \mathrm{a}$ & $\mathrm{n} / \mathrm{a}$ & $\mathrm{n} / \mathrm{a}$ & $\mathrm{n} / \mathrm{a}$ & 1.3 & 0.3 & (de la Rosa et al., 2004) \\
\hline & Puerto Angel, Mexico & $\mathrm{n} / \mathrm{a}$ & $\mathrm{n} / \mathrm{a}$ & $\mathrm{n} / \mathrm{a}$ & $\mathrm{n} / \mathrm{a}$ & 1.5 & 0.4 & (de la Rosa et al., 2004) \\
\hline & Devil's Lake State Park, WI & 9.1 & 8.3 & 5.3 & 10.1 & 1.6 & 0.3 & (Rutter et al., 2008) \\
\hline & Kenosha, WI & 24 & 18 & $\mathrm{n} / \mathrm{a}$ & $\mathrm{n} / \mathrm{a}$ & 2.2 & 0.7 & (Landis et al., 2002b) \\
\hline & Bondville, IL & 19 & 11 & $\mathrm{n} / \mathrm{a}$ & $\mathrm{n} / \mathrm{a}$ & 2.0 & 0.5 & (Landis et al., 2002b) \\
\hline & Dexter, MI & $\mathrm{n} / \mathrm{a}$ & $\mathrm{n} / \mathrm{a}$ & $2-3^{\mathrm{a}}$ & $\mathrm{n} / \mathrm{a}$ & 1.5 & $\mathrm{n} / \mathrm{a}$ & (Lynam and Keeler, 2005) \\
\hline & Athens, Ohio & 5 & 6 & 13 & 25 & 1.6 & 0.2 & (Yatavelli et al., 2006) \\
\hline & Cove Mountain, TN & 10 & 7 & 14 & 7 & 3.2 & 0.7 & (Gabriel et al., 2005) \\
\hline & Connecticut & $10-16^{\mathrm{b}}$ & $\mathrm{n} / \mathrm{a}$ & $\mathrm{n} / \mathrm{a}$ & $\mathrm{n} / \mathrm{a}$ & $2.0-3.8^{\mathrm{b}}$ & $\mathrm{n} / \mathrm{a}$ & (Nadim et al., 2001) \\
\hline & St Anicet, Quebec, Canada & 3 & 54 & 3 & 11 & 1.7 & 0.4 & (Poissant et al., 2005) \\
\hline
\end{tabular}

a range of medians reported

$\mathrm{b}$ range of averages and standard deviations reported across multiple sites

and $\mathrm{RGM}=14 \mathrm{pg} \mathrm{m}^{-3}$ ) from publications listed in Table 3 (Gabriel et al., 2005; Poissant et al., 2005). Averages were calculated from these minimum and maximum values which were used in a sensitivity test on the calculation to estimate uncertainties.

Pollution roses presented in Fig. 4a, b, and c, illustrate the percentage of mercury species that arrived at the measurement sites from wind directions consistent with the source regions and ingress trajectories identified by the Concentration Field Analysis (Fig. 3a-e). Tables accompany the pollution roses to convey the source region impacts broken down as point source and non-point source contributions to the average concentrations measured during the 17-day study period. The uncertainties presented in each table under columns labeled "unc" are the results of the previously described sensitivity analyses. The calculations revealed that the largest influxes of RM and GEM to the urban site (Fig. 4a and b) originated from Source Regions SE and W. Emissions from these regions contributed to $82 \pm 2 \%$ of the average RM concentration, and $63 \pm 1 \%$ of the average GEM measured concentration at the urban site. A comparison between the source apportionment of mercury impacts by source region and the 2004 PRTR mercury emission rates by facility indicates that it is likely that either the emissions rates published in the PRTR were inaccurate, or there were a large quantity of unregistered emissions occurring in all of the source regions, but particularly in Region W and, possibly Region SE. It should be noted that emissions from Popocatepetl Volcano may have supplemented Source Region SE, although specialized studies would be needed to successfully evaluate by how much. The larger percentages of non-point source contributions from Regions W and SE reflected the higher frequency with which air masses impinged on the site from these directions. The largest influxes of GEM to the rural site (Fig. 4c) were also observed to originate from Source Regions SE and W (the latter of which was combined with Region SW) corroborating what was observed at the urban site. Emissions from these regions contributed to $50 \pm 1 \%$ of the average GEM concentration measured at the rural site. It should be noted that due to the relative positions of the urban and rural sites, that source regions to the east of the urban site were to the south of the rural site, which was not corrected for in these analyses. 

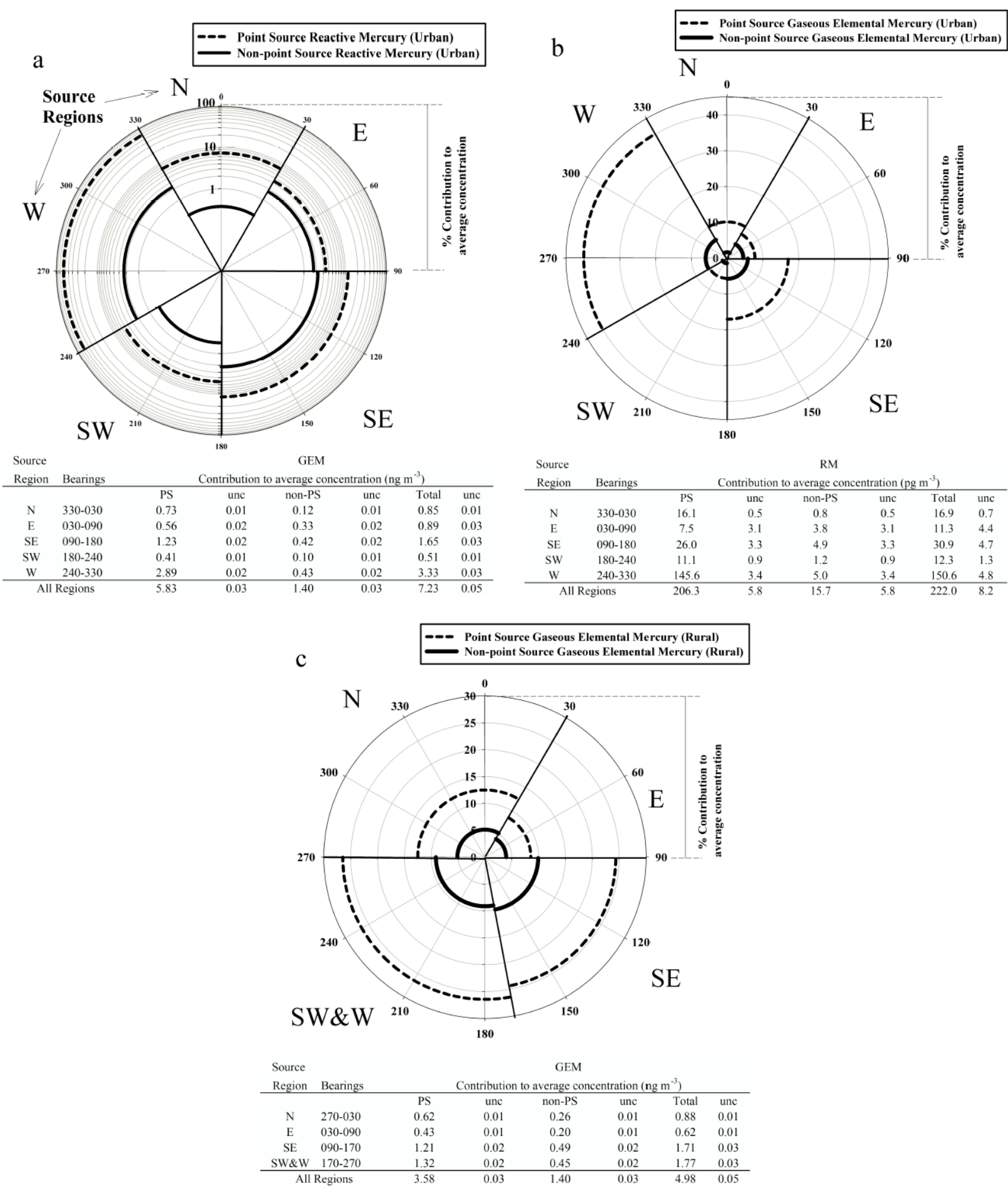

Fig. 4. Pollution roses showing the percentage contributions of the five source regions to the average concentration of reactive mercury (a), and gaseous elemental mercury (b) at the urban site, and gaseous elemental mercury at the rural site (c). Included with each pollution rose is a table presenting the data in terms of concentrations. Uncertainties (presented in the column titled "unc" in the inset tables) were derived from sensitivity studies of the calculations. 

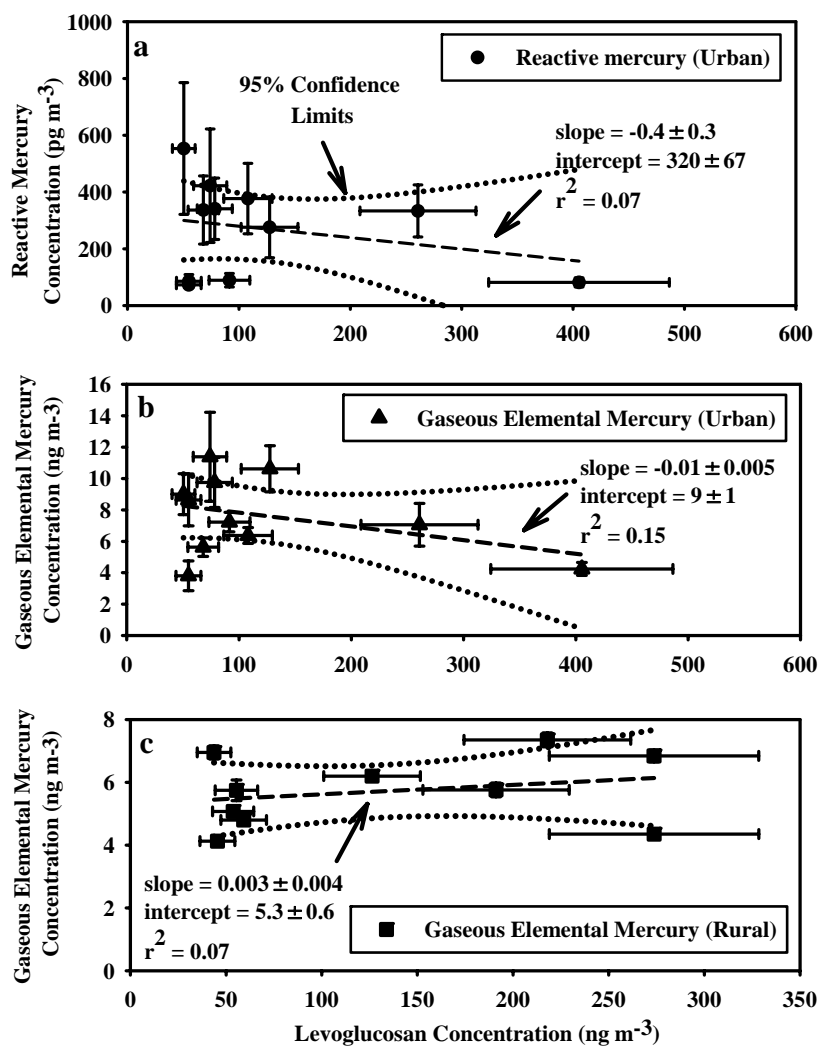

Fig. 5. Levoglucosan plotted with reactive mercury (a) and gaseous elemental mercury (b) at the urban site, and gaseous elemental mercury at the rural site (c). The uncertainties in levoglucosan represent the instrument precision. The uncertainties in reactive mercury and elemental mercury are standard errors.

3.4 Biomass burning as a source of atmospheric mercury in the MCMA

Previous published studies performed outside Mexico demonstrated biomass burning to be sources of GEM and PHg (Ebinghaus et al., 2007; Friedli et al., 2003, 2004; Hall et al., 2006). During the MILAGRO measurement campaign there were numerous wildfires burning around the MCMA (Yokelson et al., 2007), and two publications showed that biomass burning contributed substantially to the organic portion of aerosol particles (Moffet et al., 2007; Stone et al., 2007). Furthermore, cottage industries such as adobe tile and brick manufacture could constitute unregistered urban point sources of RM and GEM, due to potentially significant mercury contents of biomass fuels (Friedli et al., 2007; Raga et al., 2001). Figure 5a, b and c, investigated whether the elevated concentrations of RM and GEM at the urban site and the rural site were related to wildfires or biofuels use by examining correlations with levoglucosan (1,6-anhydro$\beta$-D-glucopyranose), a marker compound for biomass burning (Schauer and Cass, 2000; Simoneit et al., 1999; Stone et al., 2007). Neither RM nor GEM showed correlations with levoglucosan that were statistically different than 0 at the $95 \%$ confidence limit at the urban or rural sites. In addition, Yokelson et al. (2007) published times during which biomass burning plumes were sampled at the urban site, none of which corresponded to significant episodic increases in GEM or RM species at the urban site. Therefore, the majority of RM and GEM concentrations detected at the urban site were due to sources other than biomass burning. PHg and GEM concentrations associated with biomass fires reported in published studies were typically between $10-80 \mathrm{pg} \mathrm{m}^{-3}$ and less than $0.6 \mathrm{ng} \mathrm{m}^{-3}$, respectively at distances greater than $3 \mathrm{~km}$ from the fires (Friedli et al., 2003; Hall et al., 2006). Plumes containing PHg and GEM concentrations of these magnitudes could easily have been obscured by the background concentrations observed in the MCMA (Fig. 1).

\section{Conclusions}

Industrial point sources of atmospheric mercury in and around the MCMA were observed to substantially affect atmospheric mercury concentrations on a daily basis during the measurement study. Point sources included in the 2004 Federal Pollutant Release and Transfer Register (PRTR) correlated well with source regions determined using Concentration Field Analysis, illustrating the impact of facilities in and around Mexico City on atmospheric mercury measurements at the urban and rural sites. Extensive source regions were also identified (primarily to the west of the urban site) that did not correlate to entries in the PRTR and which contributed substantially to average reactive mercury and gaseous elemental mercury concentrations at the urban site. This issue will need to be investigated, and the mercury emission inventory appropriately revised to include sources under Federal, State, and Municipal jurisdiction, so that successful air quality management strategies for atmospheric mercury can be formulated and implemented in Mexico City.

Measurements indicated that mercury was predominantly speciated in the reactive form in most plumes impacting the urban site, although plume impacts of GEM were also observed at both measurement sites. Given the big difference in deposition characteristics of RM and GEM it would be prudent for future iterations of the PRTR to speciate point source emissions of atmospheric mercury.

Finally, the Popocatepetl volcano may have augmented atmospheric mercury concentrations in air masses impinging upon the urban and rural sites from the southeast. A more specialized study would need to be done to quantify the impact of Popocatepetl in relation to anthropogenic emissions upwind of the volcano in relation to upwind anthropogenic emissions near Puebla.

Acknowledgements. This study was primarily funded by the National Science Foundation (grant 0514280; PI-Schauer), and US Environmental Protection Agency Science to Achieve Results (grant R829798; PI-Schauer). The MIT/Molina Center and 
the CENICA teams would like to acknowledge support from the National Science Foundation (grant 0511803), the Mexico Metropolitan Environmental Commission and the National Institute of Ecology. We thank Jeffery Gaffney and Nancy Marley for providing meteorological data. Mike Caseley (Seajet Express Inc.) and Rafael Ramos (Ministerio del Medio Ambiente, Mexico) provided invaluable assistance with shipment logistics.

Edited by: J. Gaffney

\section{References}

Bagnato, E., Aiuppa, A., Parello, F., Calabrese, S., D’Alessandro, W., Mather, T. A., McGonigle, A. J. S., Pyle, D. M., and Wangberg, I.: Degassing of gaseous (elemental and reactive) and particulate mercury from Mount Etna volcano (Southern Italy), Atmos. Environ., 41, 7377-7388, 2007.

Biswas, A., Blum, J. D., Klaue, B., and Keeler, G. J.: Release of mercury from Rocky Mountain forest fires, Global Biogeochem. Cy., 21, GB1002, doi:10.1029/2006GB002696, 2007.

Chow, J. C., Watson, J. G., Edgerton, S. A., and Vega, E.: Chemical composition of PM2.5 and PM10 in Mexico City during winter 1997, Sci. Total Environ., 287, 177-201, 2002.

Cinnirella, S. and Pirrone, N.: Spatial and temporal distributions of mercury emissions from forest fires in Mediterranean region and Russian federation, Atmos. Environ., 40, 7346-7361, 2006.

Clarkson, T. W.: Mercury - Major Issues in Environmental-Health, Environ. Health Persp., 100, 31-38, 1993.

de Foy, B., Lei, W., Zavala, M., Volkamer, R., Samuelsson, J., Mellqvist, J., Galle, B., Martínez, A.-P., Grutter, M., Retama, A., and Molina, L. T.: Modelling constraints on the emission inventory and on vertical dispersion for $\mathrm{CO}$ and $\mathrm{SO}_{2}$ in the Mexico City Metropolitan Area using Solar FTIR and zenith sky UV spectroscopy, Atmos. Chem. Phys., 7, 781-801, 2007, http://www.atmos-chem-phys.net/7/781/2007/.

de Foy, B., Fast, J. D., Paech, S. J., Phillips, D., Walters, J. T., Coulter, R. L., Martin, T. J., Pekour, M. S., Shaw, W. J., Kastendeuch, P. P., Marley, N. A., Retama, A., and Molina, L. T.: Basinscale wind transport during the MILAGRO field campaign and comparison to climatology using cluster analysis, Atmos. Chem. Phys., 8, 1209-1224, 2008,

http://www.atmos-chem-phys.net/8/1209/2008/.

de la Rosa, D. A., Volke-Sepulveda, T., Solorzano, G., Green, C., Tordon, R., and Beauchamp, S.: Survey of atmospheric total gaseous mercury in Mexico, Atmos. Environ., 38, 4839-4846, 2004.

Denis, M. S., Song, X. J., Lu, J. Y., and Feng, X. B.: Atmospheric gaseous elemental mercury in downtown Toronto, Atmos. Environ., 40, 4016-4024, 2006.

Dommergue, A., Ferrari, C. P., Planchon, F. A. M., and Boutron, C. F.: Influence of anthropogenic sources on total gaseous mercury variability in grenoble suburban air (France), Sci. Total Environ., 297, 203-213, 2002.

Ebinghaus, R., Kock, H. H., Coggins, A. M., Spain, T. G., Jennings, S. G., and Temme, C.: Long-term measurements of atmospheric mercury at Mace Head, Irish west coast, between 1995 and 2001, Atmos. Environ., 36, 5267-5276, 2002.

Ebinghaus, R., Slemr, F., Brenninkmeijer, C. A. M., van Velthoven, P., Zahn, A., Hermann, M., O'Sullivan, D. A., and Oram, D. E.:
Emissions of gaseous mercury from biomass burning in South America in 2005 observed during CARIBIC flights, Geophys. Res. Lett., 34, L08813, doi:10.1029/2006GL028866, 2007.

Fast, J. D., de Foy, B., Acevedo Rosas, F., Caetano, E., Carmichael, G., Emmons, L., McKenna, D., Mena, M., Skamarock, W., Tie, X., Coulter, R. L., Barnard, J. C., Wiedinmyer, C., and Madronich, S.: A meteorological overview of the MILAGRO field campaigns, Atmos. Chem. Phys., 7, 2233-2257, 2007, http://www.atmos-chem-phys.net/7/2233/2007/.

Fitzgerald, W. F. and Gill, G. A.: Sub-Nanogram Determination of Mercury by 2-Stage Gold Amalgamation and Gas-Phase Detection Applied to Atmospheric Analysis, Anal. Chem., 51, 17141720, 1979.

Fraser, M. P. and Lakshmanan, K.: Using levoglucosan as a molecular marker for the long-range transport of biomass combustion aerosols, Environ. Sci. Technol., 34, 4560-4564, 2000.

Friedli, H. R., Radke, L. F., Lu, J. Y., Banic, C. M., Leaitch, W. R., and MacPherson, J. I.: Mercury emissions from burning of biomass from temperate North American forests: laboratory and airborne measurements, Atmos. Environ., 37, 253-267, 2003.

Friedli, H. R., Radke, L. F., Prescott, R., Li, P., Woo, J. H., and Carmichael, G. R.: Mercury in the atmosphere around Japan, Korea, and China as observed during the 2001 ACEAsia field campaign: Measurements, distributions, sources, and implications, J. Geophys. Res.-Atmos., 109, D19S25, doi:10.1029/2003JD004244, 2004.

Friedli, H. R., Radke, L. F., Payne, N. J., McRae, D. J., Lynham, T. J., and Blake, T. W.: Mercury in vegetation and organic soil at an upland boreal forest site in Prince Albert National Park, Saskatchewan, Canada, J. Geophys. Res.-Biogeosciences, 112, G01004, doi:10.1029/2005JG000061, 2007.

Gabriel, M. C., Williamson, D. G., Brooks, S., and Lindberg, S.: Atmospheric speciation of Southeastern mercury in two contrasting US airsheds, Atmos. Environ., 39, 4947-4958, 2005.

Hall, B. D., Olson, M. L., Rutter, A. P., Frontiera, R. R., Krabbenhoft, D. P., Gross, D. S., Yuen, M., Rudolph, T. M., and Schauer, J. J.: Atmospheric mercury speciation in Yellowstone National Park, Sci. Total Environ., 367, 354-366, 2006.

Jensen, S. and Jernelov, A.: Biological Methylation of Mercury in Aquatic Organisms, Nature, 223, 753-754, 1969.

Kainz, M., Telmer, K., and Mazumder, A.: Bioaccumulation patterns of methyl mercury and essential fatty acids in lacustrine planktonic food webs and fish, Sci. Total Environ., 368, 271282, 2006.

Kim, K. H., Ebinghaus, R., Schroeder, W. H., Blanchard, P., Kock, H. H., Steffen, A., Froude, F. A., Kim, M. Y., Hong, S. M., and Kim, J. H.: Atmospheric mercury concentrations from several observatory sites in the northern hemisphere, J. Atmos. Chem., 50, 1-24, 2005.

Landis, M. S., Stevens, R. K., Schaedlich, F., and Prestbo, E. M.: Development and characterization of an annular denuder methodology for the measurement of divalent inorganic reactive gaseous mercury in ambient air, Environ. Sci. Technol., 36, 3000-3009, 2002a.

Landis, M. S., Vette, A. F., and Keeler, G. J.: Atmospheric mercury in the Lake Michigan basin: Influence of the Chicago/Gary urban area, Environ. Sci. Technol., 36, 4508-4517, 2002 b.

Lin, C. J. and Pehkonen, S. O.: The chemistry of atmospheric mercury: a review, Atmos. Environ., 33, 2067-2079, 1999. 
Liu, S. L., Nadim, F., Perkins, C., Carley, R. J., Hoag, G. E., Lin, Y. H., and Chen, L. T.: Atmospheric mercury monitoring survey in Beijing, China, Chemosphere, 48, 97-107, 2002.

Lu, J. Y., Schroeder, W. H., Berg, T., Munthe, J., Schneeberger, D., and Schaedlich, F.: A device for sampling and determination of total particulate mercury in ambient air, Anal. Chem., 70, 24032408, 1998.

Lynam, M. M. and Keeler, G. J.: Comparison of methods for particulate phase mercury analysis: sampling and analysis, Anal. Bioanal. Chem., 374, 1009-1014, 2002.

Lynam, M. M. and Keeler, G. J.: Automated speciated mercury measurements in Michigan, Environ. Sci. Technol., 39, 92539262, 2005.

Lynam, M. M. and Keeler, G. J.: Source-receptor relationships for atmospheric mercury in urban Detroit, Michigan, Atmos. Environ., 40, 3144-3155, 2006.

Manolopoulos, H., Schauer, J. J., Purcell, M. D., Rudolph, T. M., Olson, M. L., Rodger, B., and Krabbenhoft, D. P.: Local and regional factors affecting atmospheric mercury speciation at a remote location, J. Environ. Eng. Sci., 6, 491-501, doi:10.1139/s07-005, 2007.

Manolopoulos, H., Snyder, D. C., Schauer, J. J., Turner, J. R., Olson, M. L., and Krabbenhoft, D. P.: Sources of Speciated Atmospheric Mercury at a Residential Neighbourhood Impacted by Industrial Sources, Environ. Sci. Technol., 40, 5626-5633, 2006.

Michalakes, J., Dudhia, J., Gill, D., Klemp, J., and Skamarock, W.: Design of a next-generation regional weather research and forecast model: Towards Teracomputing, World Scientific, River Edge, New Jersey, 117-124, 1998.

Moffet, R. C., de Foy, B., Molina, L. T., Molina, M. J., and Prather, K. A.: Measurement of ambient aerosols in northern Mexico City by single particle mass spectrometry, Atmos. Chem. Phys., 8, 4499-4516, 2008, http://www.atmos-chem-phys.net/8/4499/2008/.

Molina, L. T. and Molina, M. J. E.: Air Quality in the Mexico Megacity: An Integrated Assessment, Kluwer Academic Publishers, Boston, MA, USA, 2002.

Nadim, F., Perkins, C., Liu, S. L., Carley, R. J., and Hoag, G. E.: Long-term investigation of atmospheric mercury contamination in Connecticut, Chemosphere, 45, 1033-1043, 2001.

The Weather Research and Forecasting Model: http://wrf-model. org/index.php, last access: 4 March 2008.

Nolte, C. G., Schauer, J. J., Cass, G. R., and Simoneit, B. R. T.: Trimethylsilyl derivatives of organic compounds in source samples and in atmospheric fine particulate matter, Environ. Sci. Technol., 36, 4273-4281, doi:10.1021/es020518y, 2002.

Obrist, D., Moosmuller, H., Schurmann, R., Chen, L. W. A., and Kreidenweis, S. M.: Particulate-phase and gaseous elemental mercury emissions during biomass combustion: Controlling factors and correlation with particulate matter emissions, Environ. Sci. Technol., 42, 721-727, 2008.

Pavlish, J. H., Sondreal, E. A., Mann, M. D., Olson, E. S., Galbreath, K. C., Laudal, D. L., and Benson, S. A.: State review of mercury control options for coal-fired power plants, Fuel Process. Technol., 82, 89-165, 2003.

Poissant, L., Pilote, M., Beauvais, C., Constant, P., and Zhang, H. H.: A year of continuous measurements of three atmospheric mercury species (GEM, RGM and Hg-p) in southern Quebec, Canada, Atmos. Environ., 39, 1275-1287, 2005.
Querol, X., Pey, J., Minguillon, M. C., Perez, N., Alastuey, A., Viana, M., Moreno, T., Bernabe, R. M., Blanco, S., Cardenas, B., Vega, E., Sosa, G., Escalona, S., Ruiz, H., and Artinano, B.: PM speciation and sources in Mexico during the MILAGRO-2006 Campaign, Atmos. Chem. Phys., 8, 111-128, 2008,

http://www.atmos-chem-phys.net/8/111/2008/.

Raga, G. B., Baumgardner, D., Castro, T., Martinez-Arroyo, A., and Navarro-Gonzalez, R.: Mexico City air quality: a qualitative review of gas and aerosol measurements (1960-2000), Atmos. Environ., 35, 4041-4058, 2001.

Rutter, A. P., Hanford, K. L., Zwers, J. T., Perillo-Nicholas, A. L., Schauer, J. J., Worley, C. A., Olson, M. L., and DeWild, J. F.: Evaluation of an Off-line Method for the Analysis OF Atmospheric Reactive Gaseous Mercury and Particulate Mercury, Journal of Air and Waste Management Association, 58(3), 377383, doi:10.3155/1047-3289.58.3.377, 2008.

Rutter, A. P. and Schauer, J. J.: The Effect of Temperature on the Gas-Particle Partitioning of Reactive Mercury in Atmospheric Aerosol, Atmos. Environ., 41, 8647-8657, 2007a.

Rutter, A. P. and Schauer, J. J.: The Impact of Aerosol Composition on the Particle to Gas Partitioning of Reactive Mercury, Environ. Sci. Technol., 41(11), 3934-3939, 2007b.

Rutter, A. P., Schauer, J. J., Lough, G. C., Snyder, D. C., Kolb, C. J., Von Klooster, S., Rudolf, T., Manolopoulos, H., and Olson, M. L.: A comparison of speciated atmospheric mercury at an urban center and an upwind rural location, J. Environ. Monitor., 10, 102-108, 2008.

Sakata, M. and Marumoto, K.: Formation of atmospheric particulate mercury in the Tokyo metropolitan area, Atmos. Environ., 36, 239-246, 2002.

Schauer, J. J. and Cass, G. R.: Source apportionment of wintertime gas-phase and particle-phase air pollutants using organic compounds as tracers, Environ. Sci. Technol., 34, 1821-1832, 2000.

Schroeder, W. H. and Munthe, J.: Atmospheric mercury - An overview, Atmos. Environ., 32, 809-822, 1998.

Seigneur, C., Lohman, K., Vijayaraghavan, K., and Shia, R. L.: Contributions of global and regional sources to mercury deposition in New York State, Environ. Pollut., 123, 365-373, 2003.

Seigneur, C., Vijayaraghavan, K., Lohman, K., Karamchandani, P., and Scott, C.: Global source attribution for mercury deposition in the United States, Environ. Sci. Technol., 38, 555-569, 2004.

Pollutant Release and Transfer Register (Registro de Emisiones y Transferencia de Contaminantes): http://app1.semarnat.gob.mx/ retc/index.php, last access: 8 January 2008, 2006.

Sheesley, R. J., Schauer, J. J., Bean, E., and Kenski, D.: Trends in secondary organic aerosol at a remote site in Michigan's upper peninsula, Environ. Sci. Technol., 38, 6491-6500, 2004.

Simoneit, B. R. T., Schauer, J. J., Nolte, C. G., Oros, D. R., Elias, V. O., Fraser, M. P., Rogge, W. F., and Cass, G. R.: Levoglucosan, a tracer for cellulose in biomass burning and atmospheric particles, Atmos. Environ., 33, 173-182, 1999.

Simoneit, B. R. T. and Elias, V. O.: Detecting organic tracers from biomass burning in the atmosphere, Mar. Pollut. Bull., 42, 805$810,2001$.

Slemr, F., Brunke, E. G., Ebinghaus, R., Temme, C., Munthe, J., Wangberg, I., Schroeder, W., Steffen, A., and Berg, T.: Worldwide trend of atmospheric mercury since 1977, Geophys. Res. Lett., 30(4), 1516, doi:10.1029/2003g1016954, 2003.

Stohl, A., Forster, C., Frank, A., Seibert, P., and Wotawa, G.: Tech- 
nical note: The Lagrangian particle dispersion model FLEXPART version 6.2, Atmos. Chem. Phys., 5, 2461-2474, 2005, http://www.atmos-chem-phys.net/5/2461/2005/.

Stone, E. A., Snyder, D. C., Sheesley, R. J., Sullivan, A. P., Weber, R. J., and Schauer, J. J.: Source apportionment of fine organic aerosol in Mexico City during the MILAGRO experiment 2006, Atmos. Chem. Phys., 8, 1249-1259, 2008, http://www.atmos-chem-phys.net/8/1249/2008/.

Stone, E. A., Snyder, D. C., Sheesley, R. J., Sullivan, A. P., Weber, R. J., and Schauer, J. J.: Source apportionment of fine organic aerosol in Mexico City during the MILAGRO experiment 2006, Atmos. Chem. Phys., 8, 1249-1259, 2008, http://www.atmos-chem-phys.net/8/1249/2008/.

Swartzendruber, P. C., Jaffe, D. A., Prestbo, E. M., Weiss-Penzias, P., Selin, N. E., Park, R., Jacob, D. J., Strode, S., and Jaegle, L.: Observations of reactive gaseous mercury in the free troposphere at the Mount Bachelor Observatory, J. Geophys. Res.-Atmos., 111, D24301, doi:10.1029/2006JD007415, 2006.

Weiss-Penzias, P., Jaffe, D. A., Swartzendruber, P., Dennison, J. B., Chand, D., Hafner, W., and Prestbo, E.: Observations of Asian air pollution in the free troposphere at Mount Bachelor Observatory during the spring of 2004, J. Geophys. Res.-Atmos., 111, D10304, doi:10.1029/2005JD006522, 2006.
Weiss-Penzias, P., Jaffe, D., Swartzendruber, P., Hafner, W., Chand, D., and Prestbo, E.: Quantifying Asian and biomass burning sources of mercury using the $\mathrm{Hg} / \mathrm{CO}$ ratio in pollution plumes observed at the Mount Bachelor Observatory, Atmos. Environ., 41, 4366-4379, 2007.

Wiener, J. G., Knights, B. C., Sandheinrich, M. B., Jeremiason, J. D., Brigham, M. E., Engstrom, D. R., Woodruff, L. G., Cannon, W. F., and Balogh, S. J.: Mercury in soils, lakes, and fish in Voyageurs National Park (Minnesota): Importance of atmospheric deposition and ecosystem factors, Environ. Sci. Technol., 40, 6261-6268, 2006.

Wood, J.: Synthesis of Methyl-mercury Compounds by Extracts of a Methanogenic Bacterium, Nature, 220, 173-174, 1968.

Yatavelli, R. L. N., Fahrni, J. K., Kim, M., Crist, K. C., Vickers, C. D., Winter, S. E., and Connell, D. P.: Mercury, PM2.5 and gaseous co-pollutants in the Ohio River Valley region: Preliminary results from the Athens supersite, Atmos. Environ., 40, 6650-6665, 2006.

Yokelson, R. J., Urbanski, S. P., Atlas, E. L., Toohey, D. W., Alvarado, E. C., Crounse, J. D., Wennberg, P. O., Fisher, M. E., Wold, C. E., Campos, T. L., Adachi, K., Buseck, P. R., and Hao, W. M.: Emissions from forest fires near Mexico City, Atmos. Chem. Phys., 7, 5569-5584, 2007, http://www.atmos-chem-phys.net/7/5569/2007/. 